\title{
IDENTIFIKASI MUTASI PADA DAERAH DNA POLIMERASE DAN HBsAg VIRUS HEPATITIS B
}

\author{
Cysilia K Hindarto ${ }^{1}$, Tina Rostinawati ${ }^{1}$, dan Debbie S Retnoningrum ${ }^{2}$, \\ ${ }^{1)}$ Fakultas Farmasi Universitas Padjadjaran \\ ${ }^{2)}$ Sekolah Tinggi Farmasi Institut Teknologi Bandung \\ Email:cysiliakh@gmail.com
}

\begin{abstract}
ABSTRAK
Infeksi virus hepatitis B (HBV) menyebabkan hepatitis akut dan kronis, dengan angka kematian 1,2 juta per tahun di seluruh dunia. Antivirus analog nukleosida dan vaksin HBV dapat menekan perkembangan infeksi HBV namun penggunaan untuk terapi jangka panjang dilaporkan menginduksi terjadinya mutasi. Mutasi yang menyebabkan timbul mutan resisten-antivirus dan mutan lolos-vaksin menjadi kendala utama dalam pengobatan dan pencegahan infeksi HBV. Telah dilakukan penelitian untuk mengidentifikasi mutasi pada gen pengkode reverse transcriptase (RT) DNA polimerase dan HBsAg virus hepatitis B. Penelitian menggunakan 24 sampel cetakan HBV yang berasal dari penderita hepatitis B dari Medan (3), Jakarta (10), Bandung (9), Yogyakarta (1), dan Surabaya (1). Metode yang dilakukan adalah amplifikasi fragmen gen pengkode DNA polimerase dan HBsAg, konfirmasi produk PCR dengan elektroforesis gel agarosa, pemurnian produk PCR dengan GFX column kit, penentuan urutan nukleotida, dan analisis hasil penentuan urutan nukleotida. Hasil penelitian menunjukkan sampel 12273 dari Jakarta mengalami mutasi di daerah gen pengkode RT DNA polimerase. Mutasi tersebut menyebabkan substitusi asam amino M475L, V519L, L526M, dan M550V. Sampel 12273 juga mengalami mutasi pada gen pengkode HBsAg yang menyebabkan substitusi asam amino M120L, V164L, L171M, dan M195V. Mutasi tersebut terjadi di daerah yang tumpang tindih dengan gen pengkode DNA polimerase, dan di luar determinan $a$. Mutan diklasifikasikan sebagai mutan resistenantivirus dengan substitusi asam amino ganda L526M dan M550V, dan tidak ditemukan mutasi pada daerah DNA pengkode determinan $a$.
\end{abstract}

Kata kunci : HBV, RT DNA polimerase, HBsAg, Mutasi

\section{PENDAHULUAN}

Infeksi virus hepatitis B (HBV) merupakan masalah kesehatan utama dengan angka kematian 1,2 juta per tahun di seluruh dunia. Infeksi HBV dikarakterisasi dengan tingginya laju perkembangan infeksi kronis baik dengan titer viremia tinggi ataupun rendah. Infeksi HBV menyebabkan penyakit hati akut dan kronis, termasuk hepatitis kronis (tetap), sirosis, dan kanker hati (hepatocellular carcinoma) yang mengancam kehidupan (Ono-Nita et al., 1999; Seigneres et al., 2000).

Berbagai usaha dilakukan untuk menekan perkembangan infeksi $\mathrm{HBV}$, termasuk pengembangan obat antivirus dan vaksin $\mathrm{HBV}$, namun belum ada pengobatan antivirus yang efektif untuk pasien yang terinfeksi HBV secara kronis. Terapi dengan interferon cukup menguntungkan untuk sebagian pasien terinfeksi HBV kronis, namun rata-rata keseluruhan respon kurang dari $40 \%$ dan interferon memiliki dosis yang terbatas karena efek sampingnya. Replikasi DNA HBV yang berlangsung melalui transkripsi balik dari intermediet RNA pregenom menjadi dasar pengembangan analog nukleosida baru yang menginhibisi aktivitas reverse transcriptase $\mathrm{HBV}$, seperti lamivudin, famsiklofir dan lainnya sebagai alternatif 
terapi interferon (Ono-nita et al., 1999; Seigneres et al., 2000).

Lamivudin terbukti dapat menekan replikasi HBV dan memiliki sedikit efek samping sehingga digunakan untuk mengobati infeksi HBV kronis. Lamivudin juga dapat mencegah re-infeksi setelah transplantasi hati. Penggunaan lamivudin untuk pengobatan jangka panjang dilaporkan menyebabkan terjadinya resistensi virus. Pada $14 \%$ pasien yang mendapat terapi lamivudin selama 1 tahun, terjadi substitusi asam amino pada motif tirosin-metionin-aspartat-aspartat (YMDD) dalam domain C DNA polimerase HBV, dengan perubahan asam amino di kodon 552, metionin menjadi valin (M552V) atau metionin menjadi isoleusin (M552I). Substitusi asam amino lain pada domain B polimerase virus, yaitu substitusi leusin menjadi metionin pada kodon 528 (L528M), juga dilaporkan dapat muncul bersamaan dengan substitusi asam amino pada motif YMDD. Substitusi asam amino L528M sering terjadi pada pasien yang mendapat terapi famsiklofir (Ono-nita et al., 1999; Seigneres et al., 2000; Yuen et al., 2001).

Selain mutasi pada daerah gen pengkode DNA polimerase yang mengakibatkan resistensi virus, HBV juga mengalami mutasi pada gen pengkode protein permukaan (HBsAg) yang menimbulkan fenomena mutan lolosvaksin. Mutan lolos-vaksin merupakan mutan HBV yang tidak dapat dikenali oleh anti-HBsAg sehingga dapat menginfeksi individu yang sudah divaksinasi. Penelitian Aprilia pada tahun 2004 menunjukkan terdapat mutan lolos-vaksin dalam sampel isolat klinik dari empat kota di Pulau Jawa. Mutan lolos-vaksin terdapat pada sampel yang berasal dari Yogyakarta (M133T) dan Jember (G145R), serta terjadi insersi pada sampel dari Jakarta (pada kodon 117 dan antara kodon 136 dan 137) (Aprilia, 2004).

Informasi mengenai mutasi yang terjadi di daerah gen pengkode DNA polimerase dan HBsAg virus hepatitis B menjadi salah satu faktor penting dalam pengobatan dan pencegahan HBV. Keberadaan mutan HBV dapat ditentukan dengan melihat urutan nukleotida sampel HBV. Penentuan urutan nukleotida dilakukan menggunakan metode PCR (Polymerase chain reaction), suatu teknik biologi molekular untuk mereplikasi DNA secara in vitro. PCR digunakan untuk mengamplifikasi daerah tertentu dari untai DNA, dapat berupa gen tunggal, bagian dari gen, atau non-coding sequence. Umumnya PCR mengamplifikasi fragmen pendek (10 kbp) DNA (Sambrook \& Russell, 2001).

Penelitian ini bertujuan untuk mengetahui adanya mutasi pada fragmen gen pengkode DNA polimerase dan HBsAg dari sejumlah isolat HBV yang berasal dari beberapa kota di Indonesia.

\section{METODE PENELITIAN}

Penelitian INI dilakukan pada bulan Maret sampai dengan Oktober 2007 di Laboratorium Mikrobiologi Farmasi, Fakultas Farmasi, Universitas Padjadjaran, dan Laboratorium Bioteknologi Farmasi, Sekolah Farmasi ITB.

\section{Bahan}

Sampel yang digunakan merupakan cetakan HBV yang diperoleh dari Laboratorium Klinik Utama Pramita cabang Jakarta dan Bandung, kalium klorida, magnesium klorida, gelatin, etidium bromida.

\section{Alat}

Cawan petri, pipet mikro, tabung eppendorf, gelas kimia, termometer, thermal cycler, mesin PCR.

\section{Cara Kerja}

\section{Amplifikasi fragmen DNA a. Gen Pengkode HBsAg}

Primer yang digunakan ialah P1 5, CAA GGT ATG TTG CCC GTT TG 3' dan P2 5' AAA GCC CTG CGA ACC ACT GA 3' (Aprilia, 2004). Primer P1 akan menempel pada urutan nukleotida 
fragmen $S$ HBsAg pada posisi 329-348 dan primer $\mathrm{P} 2$ akan menempel pada urutan nukleotida fragmen $S$ HBsAg pada posisi 587-568. Pasangan primer ini dapat mengamplifikasi urutan fragmen genom HBV yang mengandung kodon 122 dan 160 pada gen $S$ HBsAg, yang menentukan subtipe HBV(Aprilia, 2004).

Sampel berupa isolat HBV sebanyak $5 \mu \mathrm{L}$ dicampurkan dengan larutan dapar Taq [Magnesium klorida 1,5 $\mathrm{mM}$, Tris (pH 8,3) $10 \mathrm{mM}$, kalium klorida $50 \mathrm{mM}$ dan gelatin $200 \mu \mathrm{g} / \mathrm{mL}$ ], dengan dNTP $200 \mu \mathrm{M}$, Taq polimerase $5 \mathrm{U} ; 1 \mu \mathrm{L}$ primer forward $30 \mathrm{pmol} ; 1 \mu \mathrm{L}$ primer reverse $30 \mathrm{pmol}$, dan magnesium klorida $25 \mathrm{mM}$, kemudian ditambah air suling ganda hingga $25 \mu \mathrm{L}$ (Aprilia, 2004).

\section{b. Gen Pengkode DNA Polimerase}

Primer yang digunakan ialah PfwdHBVRT 5, TGT GTC TGC GGC GTT TTA TC3' dan PrevHBVRT 5' GCA AAT(G) CCC AAA AGA CCC AC3'(Aprilia, 2004). Primer PfwdHBVRT akan menempel pada urutan nukleotida daerah reverse transkriptase (RT) DNA Polimerase pada posisi 1287-1306 dan primer PrevHBVRT akan menempel pada urutan nukleotida daerah reverse transkriptase (RT) DNA Polimerase pada posisi 1909-1928. Pasangan primer ini dapat mengamplifikasi urutan fragmen genom HBV yang mengandung gen pengkode motif YMDD (Aprilia, 2004).

Sampel berupa isolat $\mathrm{HBV}$ sebanyak 5-7 $\mu \mathrm{L}$ dicampurkan dengan larutan dapar Taq [Magnesium klorida 1,5 $\mathrm{mM}$, Tris (pH 8,3) $10 \mathrm{mM}$, kalium klorida $50 \mathrm{mM}$ dan gelatin $200 \mu \mathrm{g} / \mathrm{mL}$ ], dengan dNTP $200 \mu \mathrm{M}$, Taq polimerase 5U; 0,5 $\mu \mathrm{L}$ primer forward $30 \mathrm{pmol} ; 0,5 \mu \mathrm{L}$ primer reverse 30 pmol, dan magnesium klorida $25 \mathrm{mM}$, kemudian ditambah air suling ganda hingga $25 \mu \mathrm{L}$ (Aprilia, 2004).

Kedua PCR mix masing-masing diamplifikasi pada alat thermal cycler 96 well, dengan kondisi PCR sebagai berikut : denaturasi awal, suhu $94^{\circ} \mathrm{C}$, selama 5 menit; siklus reaksi terdiri dari denaturasi pada suhu $94^{\circ} \mathrm{C}$ selama 1 menit, penempelan pada suhu $47^{\circ} \mathrm{C}$ selama 1 menit, dan pemanjangan pada suhu $72^{\circ} \mathrm{C}$ selama 1 menit. Amplifikasi dilakukan sebanyak 35 siklus; dan pemanjangan (pada siklus terakhir) pada suhu $72^{\circ} \mathrm{C}$ selama 10 menit(Aprilia, 2004).

\section{Elektroforesis gel agarosa}

Konfirmasi produk PCR dilakukan dengan elektroforesis gel agarosa $2 \%(\mathrm{~b} / \mathrm{v})$, dengan cara membandingkan hasilnya dengan marka DNA yang sesuai serta kontrol negatif produk PCR tanpa cetakan DNA. Produk PCR ditambah dengan marka pUC19/HinfI dan loading buffer di atas kertas parafilm, dengan perbandingan 5:1, kemudian dimasukkan ke sumur agar yang telah disiapkan. Elektroforesis dilakukan pada tegangan 80-90 volt selama 75 menit. Setelah itu gel agarosa direndam dalam larutan etidium bromida selama 30 detik dan dilihat di bawah lampu UV(Aprilia, 2004).

\section{Pemurnian produk PCR dengan GFX column kit}

Fragmen DNA dalam gel yang sudah ditetapkan beratnya ditambah dapar penjerat (capture buffer) sebanyak 1 kali volum gel (10 $\mu \mathrm{L}$ untuk $10 \mathrm{mg})$. Campuran ini diinkubasi pada suhu $60^{\circ} \mathrm{C}$ sampai gel larut, kemudian disentrifugasi dengan kecepatan 3000-4000 rpm selama 30 $\operatorname{detik}($ Aprilia, 2004).

Sampel yang sudah larut dimasukkan ke dalam kolom GFX, diinkubasi selama 1 menit pada suhu ruang, kemudian disentrifugasi dengan kecepatan $12000 \mathrm{rpm}$ selama 1 menit. Filtrat yang ada di collect tube dibuang. Dapar pencuci (wash buffer) sebanyak 500 $\mu \mathrm{L}$ ditambahkan ke dalam kolom, diinkubasi, kemudian disentrifugasi kembali. Filtrat yang ada di collect tube kembali dibuang. Kolom GFX dimasukkan ke dalam tabung Eppendorf steril, ditambahkan dapar pengelusi (elution buffer) sebanyak $50 \mu \mathrm{L}$, kemudian 
diinkubasi selama 1 menit pada suhu ruang dan disentrifugasi. Filtrat yang tertampung adalah produk PCR yang murni. Hasil pemurnian dielektroforesis kembali untuk melihat kebenarannya(Aprilia, 2004).

\section{Penentuan urutan nukleotida (sekuensing)}

Penentuan urutan nukleotida dilakukan berdasarkan metode dideoksi Sangar. Primer sekuensing merupakan primer yang memiliki kemampuan menentukan urutan nukleotida sampel dari 5' ke 3'. Primer sekuensing yang digunakan 5' CAA GGT ATG TTG CCC GTT TG 3' (untuk HBsAg, sekuensing satu arah) dan pasangan primer PfwdHBVRT 5' TGT GTC TGC GGC GTT TTA TC3' dan PrevHBVRT 5' GCA AAT(G) CCC AAA AGA CCC AC3, (untuk DNA Polimerase, sekuensing dua arah). Campuran untuk sekuensing dibuat dengan mencampurkan produk PCR yang sudah dimurnikan dengan primer sekuensing, dapar Taq berkekuatan 10 kali, Taq polimerase, dNTP, ddNTP, dan stop solution (formamida 95\%; $20 \mathrm{mM}$ EDTA pH 8,0;0,05\% bromofenol biru, 0,05\% xilen silanol FF). Sekuensing dilakukan menggunakan alat DNA sequencer automatic(Aprilia, 2004).

\section{Analisis hasil sekuensing}

Homologi hasil sekuensing dianalisidengan urutan nukleotida fragmen gen pengkode DNA Polimerase yang terdapat di GenBank. Homologi hasil sekuensing juga dianalisis homologi dengan urutan nukleotida fragmen gen pengkode HBsAg subtipe adw, adr, ayw, dan ayr yang terdapat di GenBank. Penentuan asam amino dengan metode deduksi secara manual dibandingkan dengan urutan parsial asam amino RT DNA polimerase dan protein $\mathrm{S} \mathrm{HbsAg}$. Genotipe isolat ditentukan dengan membandingkan hasil sekuensing dengan urutan nukleotida homolog yang didapat dari data GenBank, menggunakan program BLAST (Leon et al., 2005).

\section{Amplifikasi Fragmen DNA dan Elektroforesis Gel Agarosa}

\section{A. Gen Pengkode HBsAg}

Sampel cetakan DNA HBV dengan nomor sampel 17-24 diamplifikasi dengan pasangan primer P1 dan P2. Hasil PCR kemudian dikonfirmasi dengan elektroforesis gel agarosa, untuk mengetahui kebenaran produk PCR. Dari delapan sampel, hanya satu sampel (sampel 19) yang memberikan pita DNA yang diinginkan (berukuran 289 pb). Sampel 19 juga memberikan pita DNA yang diinginkan (berukuran 622 pb) ketika diamplifikasi dengan pasangan primer PfwdHBVRT dan PrevHBVRT. Produk PCR sampel 19 kemudian ditentukan urutan nukleotidanya setelah sebelumnya mengalami pemurnian dari larutan. Namun ternyata konsentrasi produk PCR tidak mencukupi sehingga tidak dapat ditentukan urutan nukleotidanya.

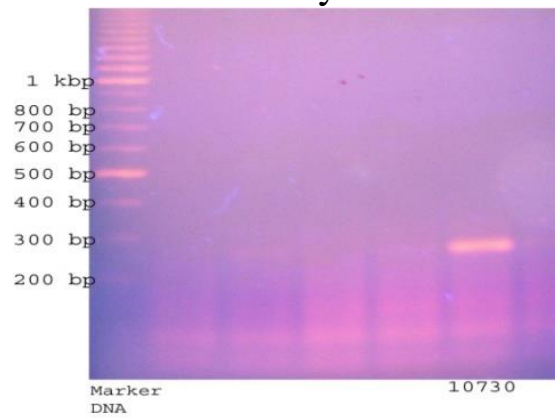

(a)

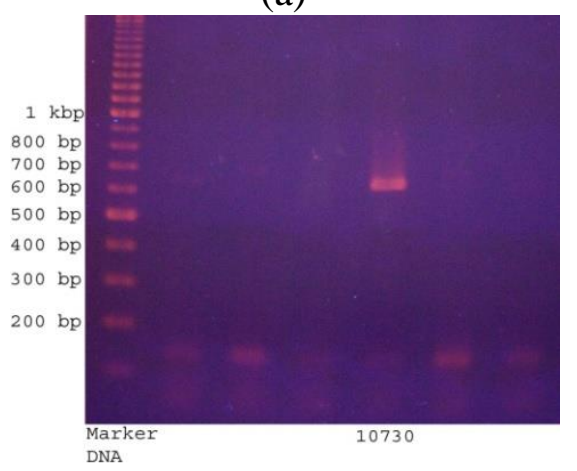

Gambar 1.Hasil elektroforesis produk PCR sampel 10730

Keterangan :
(a) dengan primer P1 dan P2
(b)dengan primer PfwdHBVRT dan
PrevHBVRT 
Sebanyak 16 sampel cetakan DNA HBV lainnya dengan nomor sampel 1-16 diamplifikasi dengan pasangan primer P1 dan P2, kemudian dikonfirmasi dengan elektroforesis gel agarosa. Dari 16 sampel, 13 sampel ( yaitu sampel 1, 4, 5, 6, 7, 8, 9, 10, 11, 12, 14, 15, dan 16) memberikan pita DNA yang diinginkan. Produk PCR kemudian dipekatkan dengan metode freeze dry dan ditentukan urutan nukleotidanya setelah sebelumnya mengalami pemurnian dari larutan. Ternyata produk PCR tidak dapat ditentukan urutan nukleotidanya karena terdapat dua pita DNA dengan ukuran yang hampir sama dalam satu produk PCR. Hal ini dapat terjadi karena primer menempel pada dua tempat (akibat kondisi PCR yang kurang tepat sehingga primer tidak spesifik menempel pada satu tempat).

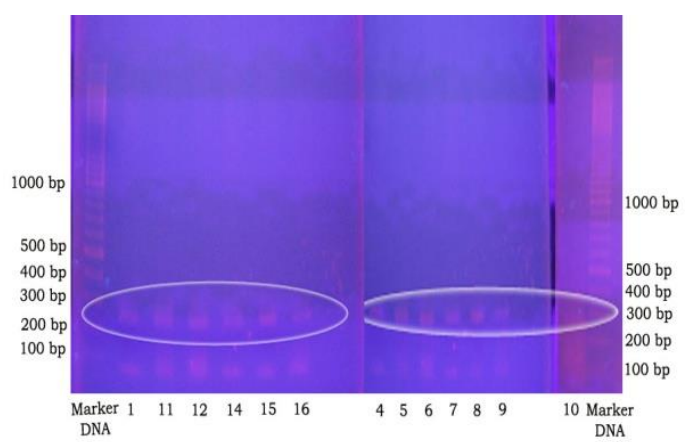

Gambar 2.Hasil Elektroforesis produk Keterangan: PCR fragmen gen HbsAg.
(1) 12141
(4) 4092
(11) 12273
(5) 11312
(12) 10367
(6) 9805
(14) 7331
(15) 10844
(7) 9730
(8) 2338
(16) 11414
(9) 8961
(10) 7784

\section{B. Gen Pengkode DNA Polimerase}

Sampel cetakan DNA HBV dengan nomor sampel 1-16 diamplifikasi dengan pasangan primer PfwdHBVRT dan PrevHBVRT, kemudian dikonfirmasi dengan elektroforesis gel agarosa untuk mengetahui kebenaran produk PCR. Dari 16 sampel, delapan sampel (sampel 8, 9, $11,12,13,14,15$, dan 16) memberikan pita DNA yang diinginkan (berukuran 622 $\mathrm{pb})$.

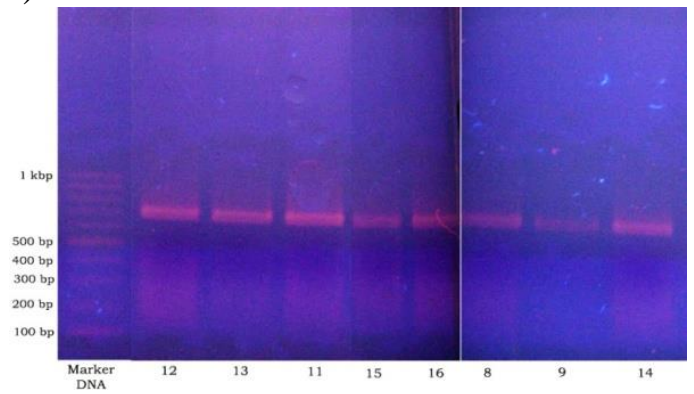

Gambar 3. Hasil Elektroforesis roduk PCR fragmen gen DNA polimerase

Keterangan :
(8) 2338
(13) 10111
(9) 8961
(11) 12273
(14) 7331
(12) 10367
(15) 10844
(16) 11414

\section{Pemurnian Produk PCR dengan GFX column kit}

Produk PCR dimurnikan dari gel dengan GFX column kit untuk menghilangkan produk dimer. Hasil pemurnian ini dielektroforesis untuk melihat kebenaran pita DNA yang dimurnikan. Elektroforesis juga dilakukan untuk menentukan konsentrasi pita DNA yang telah dimurnikan karena terjadi kehilangan konsentrasi pita akibat pemurnian.

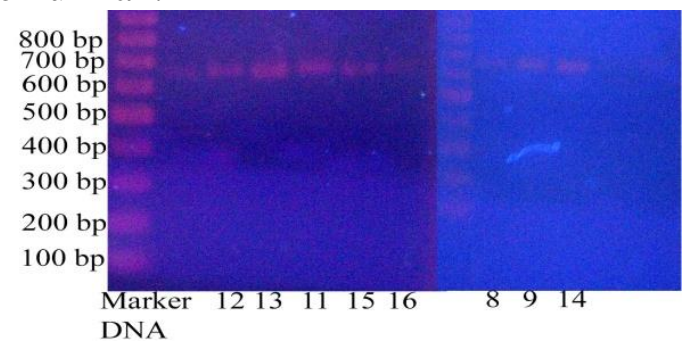

Gambar 4. Hasil Elektroforesis produk pemurnian dengan GFX column kit

Keterangan :
(8) 2338
(13) 10111
(9) 8961
(14) 7331
(11) 12273
(15) 10844
(12) 10367
(16) 11414

\section{Penentuan Urutan Nukleotida (sekuensing)}


Produk PCR yang telah dimurnikan (hasil GFX) kemudian dipekatkan dulu dengan metode freeze dry, agar konsentrasi produk PCR mencukupi untuk ditentukan urutan nukleotidanya. Delapan produk PCR masing-masing ditentukan urutan nukleotidanya dengan menggunakan sepasang primer PfwdHBVRT dan PrevHBVRT dari dua arah yang berlawanan. Primer PfwdHBVRT menentukan urutan nukleotida sampel dari 5' ke 3', sedangkan primer PrevHBVRT menentukan urutan nukleotida sampel dari 3' ke 5'.

\section{Analisis Hasil Sekuensing}

Hasil sekuensing kemudian dianalisis homologi urutan nukleotidanya dengan database yang terdapat di GenBank untuk mengetahui identitas DNA sampel, dengan menggunakan program BLAST (Basic Local Alignment Searching Tools) dari situs NCBI (www.ncbi.nlm.nih.gov). Hasil BLAST menunjukkan 4 sampel merupakan gen HBV, sedangkan 4 sampel lainnya tidak menunjukkan homologi dengan gen HBV yang ada di GenBank.

Tabel 1. Hasil BLAST Urutan Nukleotida Sampel terhadap GenBank

\begin{tabular}{|c|c|c|c|c|}
\hline $\begin{array}{c}\text { No. } \\
\text { Sampel }\end{array}$ & $\begin{array}{c}\text { Kode } \\
\text { Sampel }\end{array}$ & $\begin{array}{c}\text { Hasil BLAST } \\
\text { (Identitas } \\
\text { Sampel) }\end{array}$ & $\begin{array}{c}\text { Homo } \\
\text { logi }\end{array}$ & $\begin{array}{c}\text { Nomor } \\
\text { Akses } \\
\text { GenBank }\end{array}$ \\
\hline 8 & 2338 & - & - & \\
\hline 9 & 8961 & - & - & \\
\hline 11 & 12273 & $\begin{array}{c}\text { HBV genotipe } \\
\text { C }\end{array}$ & $98 \%$ & $\begin{array}{c}\text { AF5339 } \\
83\end{array}$ \\
\hline 12 & 10367 & $\begin{array}{c}\text { HBV genotipe } \\
\text { B }\end{array}$ & $95 \%$ & $\begin{array}{c}\text { DQ4637 } \\
93\end{array}$ \\
\hline 13 & 10111 & $\begin{array}{c}\text { HBV subtipe } \\
\text { adw }\end{array}$ & $91 \%$ & $\begin{array}{c}\text { AB2194 } \\
30\end{array}$ \\
\hline 14 & 7331 & - & - & 93 \\
\hline 15 & 10844 & $\begin{array}{c}\text { HBV genotipe } \\
\text { B }\end{array}$ & $94 \%$ & $\begin{array}{c}\text { DQ4637 } \\
93\end{array}$ \\
\hline 16 & 11414 & - & - & \\
\hline
\end{tabular}

Hasil sekuensing

(urutan nukleotida) sampel 11, 12, 13, dan 15 disejajarkan (aligned) dengan gen pengkode DNA Polimerase dari database GenBankuntuk melihat ada tidaknya mutasi pada daerah gen pengkode reverse transcriptase (RT) DNA Polimerase HBV, terutama pada daerah yang mengkode motif YMDD di domain C. Penjajaran (alignment) juga dilakukan dengan menggunakan program BLAST dari situs NCBI. Hasil alignment tersebut menunjukkan bahwa satu sampel (sampel 12273) mengalami perubahan urutan nukleotida (mutasi) pada fragmen gen pengkode DNA polimerasenya.

Sampel 12273 menunjukkan homologi $98 \%$ dengan gen pengkode DNA polimerase HBV (nomor akses AF533983), terdapat perubahan urutan nukleotida di empat titik pada daerah gen pengkode RT DNA polimerase, termasuk pada motif YMDD (lihat tabel 2). Sampel 12, 13, dan 15 tidak mengalami perubahan urutan nukleotida (mutasi) pada daerah gen pengkode RT DNA Polimerase.

Tabel 2. Perubahan Urutan Nukleotida dan Asam amino Sampel 12273

\begin{tabular}{|c|c|c|c|c|}
\hline Kodon & $\begin{array}{c}\text { Urutan } \\
\text { nukleotida } \\
\text { wildtype }\end{array}$ & $\begin{array}{c}\text { Urutan } \\
\text { nukleotida } \\
\text { mutan }\end{array}$ & $\begin{array}{c}\text { Asam } \\
\text { amino } \\
\text { wildtype }\end{array}$ & $\begin{array}{c}\text { Asam } \\
\text { amino } \\
\text { mutan }\end{array}$ \\
\hline 475 & ATG & CTG & M & L \\
\hline 519 & GTG & CTG & V & L \\
\hline 526 & CTG & ATG & L & M \\
\hline 550 & ATG & GTG & M & V \\
\hline
\end{tabular}

Analisis lebih lanjut dilakukan dengan melihat apakah perubahan urutan nukleotida di atas berpengaruh pada asam amino yang dihasilkan. Urutan nukleotida keempat sampel ditranslasikan menjadi asam amino dengan menggunakan program DNA Translate Tools dari situs ExPasy (www.expasy.ch). Hasil translasi masingmasing sampel disejajarkan dengan hasil translasi gen pengkode DNA polimerase dari GenBank (AF533983, AB219430, dan DQ463793). Penjajaran dilakukan dengan program SIM (Alignment of Two Protein Sequences) dari situs ExPasy. Jika terjadi perubahan asam amino yang dihasilkan, maka sifat-sifat asam amino tersebut dilihat 
untuk memprediksi apakah mutasi tersebut berpengaruh pada sifat mutan HBV secara keseluruhan, termasuk resistensi terhadap antivirus maupun vaksin.

Keempat perubahan urutan nukleotida sampel 12273 menyebabkan perubahan asam amino yang dihasilkan. Perubahan urutan nukleotida di kodon 475 menyebabkan perubahan metionin menjadi leusin. Metionin merupakan asam amino dengan rantai samping mengandung sulfur, sedangkan leusin merupakan asam amino dengan rantai samping alifatik. Kedua asam amino memiliki sifat yang mirip/hampir sama yaitu nonpolar, netral dan hidrofob. Kedua mutasi yang menyebabkan perubahan asam amino tersebut merupakan mutasi yang terjadi di luar daerah gen pengkode asam amino motif YMDD. Perubahan urutan nukleotida di kodon 519 menyebabkan perubahan valin menjadi leusin. Kedua asam amino ini termasuk ke dalam golongan yang sama, asam amino dengan gugus $\mathrm{R}$ alifatik. Perubahan urutan nukleotida di kodon 526 menyebabkan perubahan leusin menjadi metionin. Perubahan urutan nukleotida di kodon 550 menyebabkan perubahan metionin menjadi valin. Metionin merupakan asam amino dengan rantai samping mengandung sulfur, sedangkan valin merupakan asam amino dengan rantai samping alifatik. Kedua asam amino tersebut memiliki sifat yang mirip/hampir sama yaitu nonpolar, netral dan hidrofob.

Perubahan urutan nukleotida (mutasi) pada daerah gen pengkode RT DNA polimerase yang ingin dilihat terutama pada motif YMDD di domain C. Sampel 12273 menunjukkan mutasi M550V pada motif YMDD, menghasilkan mutan YVDD. Motif YMDD merupakan daerah yang sangat terlindungi (highly conserved domain) dalam DNA polimerase dan terlibat dalam pengikatan nukleotida ke sisi katalitik polimerase. Telah dilaporkan bahwa mutasi pada motif YMDD yang menghasilkan varian YIDD/YVDD mengubah sifat reverse transcriptase (RT), sehingga mengakibatkan turunnya kemampuan mutan untuk bereplikasi dibandingkan dengan wild type. Urutan YM dari motif YMDD berinteraksi dengan kompleks template-primer. Metionin (M) memiliki interaksi kuat dengan gugus gula dari nukleotida terminal template dan juga potensial untuk mempengaruhi secara langsung ikatan dNTP. Substitusi M menyebabkan perubahan pada posisi kompleks template-primer dan kemampuan ikatan dNTP, yang kemudian dapat mengakibatkan ketidakmampuan replikasi (Ono-Nita et al., 1999).

Selain mengakibatkan turunnya kemampuan replikasi, perubahan satu asam amino pada motif YMDD sudah cukup untuk menginduksi terjadinya resistensi terhadap lamivudin (antivirus). Substitusi asam amino $\mathrm{M}$ menjadi I atau $\mathrm{V}$ pada motif YMDD menyebabkan virus dapat membedakan lamivudin (analog dCTP) dari dCTP. Akibatnya virus menjadi resisten terhadap lamivudin (antivirus).

Substitusi asam amino M552V (M550V untuk genotipe B) sering muncul bersamaan dengan substitusi leusin 528menjadi metionin. Kedua mutan ini, M552V dan L528M merupakan mutan yang paling sering diidentifikasi dalam berbagai penelitian mengenai mutan resisten-lamivudin. Mutan resistenlamivudin diklasifikasikan menjadi mutan dengan mutasi ganda, L528M dan M552V, serta mutan dengan mutasi tunggal M552I (Seigneres et al., 2000; Yeh et al., 2000).

Pada sampel 12273 juga terdapat substitusi asam amino L526M di mana leusin digantikan oleh metionin. Perubahan ini berada pada domain B RT DNA polimerase. Terjadinya perubahan urutan nukleotida pada gen pengkode DNA polimerase sampel 12273 telah menyebabkan substitusi asam amino L526M dan M550V yang identik dengan substitusi asam amino L528M dan M552V. Dengan demikian, sampel 12273 dapat diklasifikasikan sebagai mutan resisten- 
lamivudin (antivirus) dengan substitusi asam amino ganda.

Secara klinis, strain dengan substitusi asam amino ganda L526M dan M550V/I merupakan mutan resistenlamivudin yang paling sering muncul. Substitusi asam amino M550V dan L526M masing-masing menurunkan efisiensi replikasi sebanyak 100 dan enam kali. Adanya tambahan substitusi L526M terhadap M550V memiliki efek meningkatkan laju replikasi mutan M550V. Derajat resistensi virus terhadap lamivudin adalah sebagai berikut : L526M/M550V = M550V > L526M >wildtype (Lam et al., 2004).

Gen pengkode HBsAg (protein S) HBV tumpang tindih (overlapping) dengan gen pengkode pengkode DNA Polimerase. Overlapping terjadi pada kodon 354-581 daerah RT DNA Polimerase, termasuk domain C (YMDD). Dengan demikian perubahan urutan nukleotida pada daerah gen pengkode HBsAg (protein S) juga dapat dilihat (Gambar 5).

HBV DNA
Gambar 5. Skema Overlapping gen
pengkode HBsAg dan DNA
polimerase HBV

Sampel 12273 menunjukkan homologi $98 \%$ dengan gen pengkode HBsAg HBV (nomor akses AF533983), terdapat perubahan urutan nukleotida pada 4 titik di daerah gen pengkode $\mathrm{HBsAg}$ (tabel 3). Sampel 12, 13, dan 15 tidak mengalami perubahan urutan nukleotida (mutasi) di daerah gen pengkode HBsAg.
Tabel 3. Perubahan Urutan Nukleotida dan Asam amino HBsAg Sampel 12273

\begin{tabular}{|c|c|c|c|c|}
\hline Kodon & $\begin{array}{c}\text { Urutan } \\
\text { nukleotida } \\
\text { wildtype }\end{array}$ & $\begin{array}{c}\text { Urutan } \\
\text { nukleotida } \\
\text { mutan }\end{array}$ & $\begin{array}{c}\text { Asam } \\
\text { amino } \\
\text { wildtype }\end{array}$ & $\begin{array}{c}\text { Asam } \\
\text { amino } \\
\text { mutan }\end{array}$ \\
\hline 120 & ATG & CTG & M & L \\
\hline 164 & GTG & CTG & V & L \\
\hline 171 & CTG & ATG & L & M \\
\hline 195 & ATG & GTG & M & V \\
\hline
\end{tabular}

Mutasi pada daerah gen pengkode DNA Polimerase dapat mempengaruhi ekspresi HBsAg, terutama jika substitusi asam amino terjadi pada protein $\mathrm{S}$ di mana terletak informasi penting yang dibutuhkan untuk memproduksi partikel $\mathrm{HBsAg}$. HBsAg merupakan antigen viral yang pertama muncul yang dapat dideteksi selama infeksi HBV. HBsAg mengandung determinan $a$ yang membentuk basis respon untuk anti-HBs pada imunisasi HBsAg atau infeksi HBV wildtype. Mutasi pada determinan a mempengaruhi efek vaksin $\mathrm{HBV}$ dan menyebabkan timbulnya fenomena mutan lolos-vaksin (vaccineescaped mutant). Determinan $a$ mencakup kodon 122-147 yang terletak pada Major Hidrophylic Region (MHR). Dari keempat sampel, tidak ada yang menunjukkan perubahan nukleotida di daerah determinan $a$ (kodon 122-147).

\section{SIMPULAN}

Hasil penentuan keberadaan mutan HBV menunjukkan bahwa terjadi mutasi pada gen pengkode reverse transcriptase (RT) DNA polimerase yang menyebabkan substitusi asam amino M475L, V519L, L526M, dan M550V pada sampel 12273 dari Jakarta (1 dari 24 sampel atau 0,04\%). Mutan diklasifikasikan sebagai mutan resisten-antivirus dengan substitusi asam amino ganda L528M dan M552V.

\section{DAFTAR PUSTAKA}

Aprilia, H. 2004. Mutan Lolos-Vaksin dan Subtipe Virus Hepatitis B dari Empat Kota di Pulau Jawa [Skripsi]. Bandung: Sekolah Farmasi ITB. 
Lam, W.; Y. Li; J.Y. Liou; G.E. Dutschman; and Y.C. Cheng. 2004. Reverse Transcriptase Activity of Hepatitis B Virus (HBV) DNA Polymerase within Core Capsid: Interaction with Deoxynucleoside Triphosphates and Anti-HBV L-Deoxynucleoside Analog Triphosphates. Mol Pharmacol 65:400-406.

Leon, B.; L. Taylor; M. Vargas; R.B. Lutfig; F. Albertazzi; L. Herrero; and K. Visona. 2005. HBx M130K and V131I (T - A) mutations in HBV genotype $\mathrm{F}$ during follow-up study in chronic carriers. Virology Journal; 2:60 doi:10.1186/ 1743-422X-2-60. Available online at http://www.virologyj.com/content/2/1/ 60 [diakses Desember 2006].

Ono-Nita, S.K.; N. Kato; Y. Shiratori; T. Masaki; K.H. Lan; F.J. Carrilho; and M. Omata. 1999. YMDD Motif in Hepatitis B Virus DNA Polymerase Influences on Replication and Lamivudine Resistance: A Study by In Vitro Full-Length Viral DNA Transfection. Hepatology; 29:939-945.
Sambrook, J. and D.W. Russell. 2001. Molecular Cloning: A Laboratory Manual; $3^{\text {rd }}$ ed. New York: Cold Spring Harbor Laboratory Press. p.5

Seigneres, B.; C. Pichoud; S.S. Ahmed; O. Hantz; C. Trepo; and F. Zoulim. 2000. Evolution of Hepatitis B Virus Polymerase Gene Sequence during Famciclovir Therapy for Chronic Hepatitis B. JID; 181:1221-1233.

Yeh, C.T.; R.N. Chien; C.M. Chu; and Y.F. Liaw. 2000. Clearance of the Original Hepatitis B Virus YMDD-Motif Mutants With Emergence of Distinct Lamivudine-Resistant Mutants During Prolonged Lamivudine Therapy. Hepatology; 31:1318-1326.

Yuen, M.F.; E. Sablon; C.K. Hui; H.J. Yuan; H. Decraemer; and C.L. Lai. 2001. Factors Associated With Hepatitis B Virus DNA Breakthrough in Patients Receiving Prolonged Lamivudine Therapy. Hepatology; 34:785-791. 
Fitofarmaka, Vol. 1 No.2, Pebruari 2011: 22-30 